\title{
Criminal policy on cyberbullying toward children
}

\author{
Wenggedes Frensh* and Mahmud Mulyadi \\ Doctoral Program in Law, Graduate School, Universitas Sumatera Utara, Medan, Indonesia
}

\begin{abstract}
Currently, the information and communication technology is experiencing a rapid development. Technological advances also trigger a variety of crimes (cybercrime). Cybercrime is a term that refers to criminal activities using computer and its network. One of the developing cybercrimes today is cyberbullying. The National Conference of State Legislatures describes this crime as an act of harassing and threatening others intentionally and repeatedly. In developed countries, serious efforts have been made to combat cyberbullying. While the awareness of cyberbullying threat as a crime is still low in Indonesia, there is no clear legal rule regarding this crime. This study used the theory of criminal policy and theory of criminal law reform. There are two impacts caused by the absence of the law. First, the difficulty of running a criminal policy. Second, cyberbullying has a psychological impact on victims such as a frustration, a depression, and even a suicidal intention. The result of the research showed that in terms of a penal policy, Indonesia applies the Electronic Information and Transactions Law (UU ITE) No.19 of 2016 in dealing with cyberbullying with cyberharassment type in article 27 paragraph 3 and cyberstalking in article 27 paragraph 4 after comparing with Arkansas code $2012 \S 5-71-217$. In terms of a non-penal policy, moral approach, technological approach, and media role are used.
\end{abstract}

\section{Introduction}

Globalization creates a limitless relationship between countries around the world. The interconnectedness of all countries in the world leads to the development of information and communication technology. The sophistication of information and communication technology also has an impact on the cybercrime.

Cybercrime is a term used for criminal activities using a computer and its network. [1] The types of a cybercrime include online auction fraud, check fraud, credit card fraud, identity fraud, child pornography, online prostitution and others. [2] One of the developing cybercrimes is cyberbullying.

The National Conference of State Legislatures (NCSLs) describes cyberbullying as an intentional repeated use of cell phones, computers and other electronic communication devices to harass and threaten others. [3]

\footnotetext{
*Corresponding Author: law_weng@yahoo.com
} 
Based on the statistical data of Indonesian Association of Internet Service Providers, the number of internet users in Indonesia in 2017 was 143.26 million or about $54.68 \%$ of the total population of Indonesia (262 million people). [4] The internet users in Indonesia will increase through a demographic bonus. Indonesia will receive a demographic bonuses in 2020-2030 where the number of people aged $15-65$ will be $70 \%$, and $30 \%$ of the population are non-productive people (under 15 years and above 65 years of age). [5]

The data obtained from a research on the impact of cyberbullying on children in Indonesia showed that out of 353 teenager respondents, consisting of 157 men and 196 women with the age range of 12-15 years, the number of cyberbullying victims among teenagers reached almost half of the respondents, that is 172 respondents (49\%). This means that almost one in two respondents had been a victim of cyberbullying. And, the most-widely-used media by cyberbullying perpetrators were Facebook, SMS, and Instagram. The kinds of cyberbullying experienced by the victims were in the form of mockery, slander, threat, and gossip objects. [6] Cyberbullying has a harmful effect on its victims such as a frustration, a depression, and even a suicidal intention. [7] Cyberbullying is a social problem and it needs social science and law to overcome it. [8]

Therefore, a comparison is done with one of the countries that has complete rules and definition of cyberbullying action. Arkansas which is one of the states in America has a cyberbullying rule in Arkansas Code 5-71-217. In addition, technological and communication developments exist in America, so of course America has a policy and cyberbullying crime that uses technology as a means of crime.

In relation to legislation, Indonesia still has no specific rules on cyberbullying. The rules on this matter are still generally accommodated in Law No. 19 of 2016 on Electronic Information and Transactions.

There is a need to compare how other countries apply such legislation to be a reference. Indonesia needs to learn the best practice of other countries in coping with cyberbullying and criminal policies to protect the children.

\section{Formulation of the Problem}

The problem of this research was: how should Indonesia adopt Penal and Non-Penal Policy on Cyberbullying toward children?

\section{Research Method}

This research was a normative legal research. Normative legal research is the study of positive legal norms, principles, principles and legal doctrines. In addition, it also used a comparative juridical study by conducting comparative studies of criminal law regulations in other countries in governing cyberbullying. The data of this study was the secondary data consisting of (a) main legal materials in the form of a legislation, and (b) secondary legal materials including books and journals. The data were collected using literature reviews and document analysis relating to penal and non-penal policies. A criminal policy theory was applied in considering that the prevention of cyberbullying uses both penal and non-penal efforts.

\section{Discussion}

\subsection{Penal Policy on Cyberbullying}


Wiener (1961)in his book "Cybernetics or Control and Communication in the Animal and the Machine" introduced the term cyber in cyberspace, cybercrime, and cyberlaw. [9] This term evolved from the use of cybernetic terminology by the word cyber, which stands for cyberspace and derived from the word cybernetics and space. [10] The term cyberspace first appeared in William Gibson's novel Neuromancer. [11] In 1990, John Barlow applied the term cyberspace to refer to the online world connected to the internet. [12]

Ken Rigby defines Bullying as a desire to harm and is shown through actions to cause a person to suffer. The actions are performed directly by a stronger, irresponsible person or group, usually repetitive and with a feeling of happiness. [13] These bullying actions are divided into four types: physical, verbal, relational, and cyber actions. [14]

Cyberbullyingin Arrigo (2014) book "Encyclopedia of Criminal Justice Ethics" provides an explanation of an action that includes the use of technology (including messaging, social media, and short message delivery) aimed at hurting or embarrassing other individuals. Although age factor is not important, cyberbullying is usually associated with early age (children). [15] Chadwick (2014) his book "Impacts of Cyberbullying, Building Social and Emotional Resilience" describes the following types of cyberbullying: [16]

- Harassment or disturbance by sending rough and annoying messages continuously without interruption.

- Denigration or defamation lies in spreading misleading information about others in web pages, emails, and short messages or it may come in digitally modified photographs.

- Flaming or extreme messaging is an online battle or an extreme exchange of opinions by using electronic messages in chat forums or by sending emails containing vulgar words.

- Impersonation or imitation is an entry into an email or social network which uses a person's online identity to transmit rude or embarrassing things about others.

- Masquerading or pretense is to pretend to be someone else by creating fake emails or fake short messages.

- Pseudonyms or shadow/disguise is using a pseudonym to cover the original identity. The cyberspace can recognize the perpetrator from his pseudonym that may be dangerous or insulting.

- Outing and Trickery or deception and dissemination of a secret is the act of publicly displaying or copying and resubmitting text messages, emails or instant messages relating to a person's secrets in order to embarrass him.

- Cyberstalking or cyber prowling is a form of disruption that uses the virtual world to threaten the safety of others. Usually, messages are sent via emails, text messages as well as personal communication tools.

\subsection{Law No. 19 of 2016 on Electronic Information and Transaction (EIT)}

Based on the provisions of the articles of Chapter XI concerning the criminal provisions of the EIT Law, some prohibited acts (elements of criminal offense) that are closely related to cyberbullying in each article can be identified as follows:

Article 27 Paragraph 3 stipulates the prohibition to distribute, transmit and make accessible any form of Electronic Information or Electronic Document which has contents of an insult or defamation. The word insult or defamation categorized in cyberspace comes under the type of harassment and denigration cyberbullying.

The elements of crime contained in the Laware as follows: 
- Deliberately. Deliberately means doing something with a consciousness and knowing the consequences of the deed. In harassment and denigration cyberbullying, an act is done by sending messages insultingly to attack somebody's honor. The act is done continuously without interruption. The act explains that the perpetrator performs his actions intentionally and knows the consequences of his actions. In this case, the element of deliberately is met.

- Without rights is an act against the law that violates the provisions of the legislation. In cyberharassment, without rights means that the offender has no legal permission to do so.

- Distribute and/or transmit and/or make accessible any form of Electronic Information and/or Electronic Documents. Distributing means sharing or submitting something. Distributing here means to send an electronic information or electronic document, either to someone or some parties by utilizing the information and communication technology. The other element, transmitting, include sending or forwarding an electronic information or electronic document to somebody. Distributing shares something to many people, while transmitting to one person only.

- Having contents of an insult and defamation in the EIT Law refers to the provisions of an insult or defamation set forth in the Criminal Code (Penal Code). The essence of an insult or defamation in the EIT and the Penal Code is an act of attacking the honor or reputation of others in order to be known by the public.

Article 27 Paragraph 4 stipulates the prohibition to distribute, transmit and make accessible any form of Electronic Information or Electronic Document that has blackmailing or threating contents. The word blackmail or threat used in the cyberspace is categorized into cyberstalking.

The elements of a crime contained in the Law are as follows:

Article 27 Paragraph 4 of the Law on EIT refers to the blackmailing and threating acts regulated in Chapter XXIII Book II of the Penal Code. Blackmailing and threating in cyberspace are not done physically but by forcefully threatening somebody to defame or disclose his secrets by using information technology as a tool. This type of cyberbullying is referred to as cyberstalking.

\subsection{Arkansas Code 2012 § 5-71-217 on Cyber bullying}

Zweigert and Kotz explain the comparative law of an intellectual activity, where a law acts as an object and comparison as a process. [17] Comparative law provides an understanding of the nature of a law and its development. [18] Cyberbullying legislation is regulated in one of the American States called Arkansas. The definition of cyberbullying and what kind of actions categorized into cyberbullying can be found in Arkansas Code 2012 § 5-71-217. So, it is necessary to know the rules of cyberbullying in Arkansas as part of a comparative law study, given that the information and knowledge have connected people around the world. [19]

Arkansas Code 5-71-217 describes that the cyberbullying occurs when someone transmits, sends, or posts a communication by electronic means in order to frighten, force, intimidate, threaten, abuse, humiliate, and warn others. Transmitting here means continuing to engage in severe, repetitive or hostile behavior toward others.

Posting communication means the communication of a person's information without any change in the form or content of the information sent and received. Whereas electronic means refers to textual, visual, written, or oral communication through the use of online computer services, internet services, telephone, or other means of communication, which also covers bulletin board services, internet chat rooms, electronic mails, social networking sites and online messaging services. 
Transmitting, sending or posting communication by electronic means has been regulated in each criminal provision of the EIT Law. If the act is intended to frighten, force, intimidate and threaten, then the act comes under Article 27 Paragraph 4 on blackmailing and threating. As to insulting act, it has been regulated in Article 27 Paragraph 3 on insult and defamation.

Performing cyberbullying repeatedly is categorized into the element of deliberately. A deliberate act means doing something well or repeatedly and knowing the consequences arising from the act. The use of electronic means by making textual, visual, written or oral communications in the EIT Law comes under the electronic information. When electronic information enters the virtual world by using online computer services, internet services, telephones and other means of communication, it becomes an electronic document.

\subsection{Non-Penal Policy on Cyberbullying}

\subsection{Moral Approach}

Efforts to implement moral education can be done by families through education. Borba(2008) in her book "Building Moral Intelligence" explains that families can give 7 moral teachings to children. Moral education is very important considering that cyberbullying is done by insulting and slandering someone in the cyberspace. It is important to teach children to know empathy; to have a conscience, self-control, mutual respect; to nurture goodness; to maintain tolerance; and to be fair. [20] If a moral approach is done, then a sense of a mutual respect and creating a welcoming environment will avoid cyberbullying.

\subsection{Technological Approach}

Parental control applications and filters are used to protect children's security on the internet. [21] Parental control applications can be installed such as Qustodio, K9 Web Protection, Kakatu and DNS Nawala. [22] The above software is used to know the activities of the children in a cyberspace when connected to the internet such as what sites they often $\log$ in. This software gives a warning if the sites visited have a malicious content.

\subsection{The Role of Media}

\subsubsection{Television}

Appearances of the contain that contain harsh, disrespectful, sexual and other negative views will affect television viewers. [23] Children as spectators will tend to imitate everything seen from the television media. [24] If a child imitates negative things such as abusive, disrespectful, sexual and other negative things, they will trigger actions related to cyberbullying. The reason why many television shows today are less educational is because the censorship institutions, television and Indonesian Broadcasting Commission (KPI) are paying less special attention to this matter. [25] So, television shows are often loaded with a lot of harsh word contents.

\subsubsection{Online Media}


Here are some media on the internet which are often used and visited by children that require parental supervision in order to prevent the occurrence of cyberbullying:

\subsection{Social Networking}

Cyberbullying cases are dominated by social networking and many suicidal cases occurred due to the introduction of social networking. [26] Any person who uses the network can be a victim of cyberbullying. [27] Most internet users among teenagers use social networks like Facebook, Instagram, and Twitter. [28] The regulation of ethics when using social networking is very important. [29] It is intended that every social network users, especially children can feel safe. Ethical arrangements in everyday life which have been done with a moral approach must also be supported with ethics in the cyberspace.

\subsection{Video Web (Video Hosting Service)}

Video Web is a video-sharing site provided to share both private and public documentaries. One of the famous video websites is Youtube. [30] In a video web like Youtube, there is a great number of uploaded videos with contents of insulting and abusive words. Videos with contents of insulting words will have a negative impact on the audience, which are mostly children who often imitate the things seen. [31]

\subsection{Online Game}

Online games, which are facilitated by communication buttons, open up opportunities for cyberbullying if players use harsh words and intimidate other players. One of the most frequent online games which is subject to cyberbullying is a game that comes from the New Zealand called smallworlds. [32] This game comes under a friendship category which connects many players from various countries around the world. Providing education to children related to the use of good and safe online games is important to protect them from cyberbullying.

\section{Conclusions}

\subsection{Summary}

The findings show that the existing criminal policies in Indonesia on cyberbullying, both in terms of penal and non-penal policies, can be used in overcoming cyberbullying problems. In terms of a penal policy, Indonesia applies the EIT Law No. 19 of 2016 in dealing with cyberbullying with cyberharassment type in article 27 paragraph 3 and cyberstalking in article 27 paragraph 4 after comparing with Arkansas code $2012 \S 5-71-217$. In terms of a non-penal policy, moral approach, technological approach, and media role are used.

\subsection{Suggestions}

The penal policy using the EIT Law No. 19 of 2016 should be implemented firmly as a repressive effort in combating cyberbullying. In addition, non-penal policies should take precedence as preventive measures in tackling cyberbullying, meaning that non-penal policies should be improved by using the moral approach, the technological approach, and the role of the media. 


\section{References}

1. R. Moore, Cybercrime: Investigating High-Technology Computer Crime, p. 15 (Anderson Publishing, Mississippi, 2011)

2. D. Juju and F. Sulianta, Hitam danPutih Facebook, p. 73 (PT Elex Media Komputindo, Jakarta, 2010)

3. C. D. Marcum, Cybercrime, p. 100 (Wolters Kluwer Law \& Business, New York, 2015)

4. K. Ayuwuragil, Pengguna Internet IndonesiaCapai 143 Juta. www.cnnindonesia.com/teknologi/pengguna-internet-indonesia-capai 143-juta appdev.2018.04.007

5. A. Rosari, Bonus Demografi dan Dampak Terhadap Indonesia. www.kompasiana.com/andhinirosari/bonus-demografi-dan-dampak-terhadapindonesia appdev.2018.04.007

6. Sartana \& N. Afriyeni, Perilaku Perundungan Maya Cyberbullying Pada Remaja Awal, Jurnal Psikologi Insight, Vol.1,25-41 (2017)

7. R. Luppicini, Ethical Impact of Technological Advancements And Applications in Society, p. 121 (Information Science Reference, United State, 2012)

8. M. Andrew, Information Technology Law: The Law and Society, p. 157 (Oxford University Press, New York, 2013)

9. N. Wiener, Cybernetics or Control and Communication in the Animal and the Machine, p. 11(MIT Press, Massachusetts, 1961)

10. J. Sitompul, Cyberspace, Cybercrimes, Cyberlaw: Tinjauan Aspek Hukum Pidana, p. 4 (Tatanusa, Jakarta, 2012)

11. R.C. Lee and S.C Wong, Asian America.Net: Ethnicity, Nationalism, and Cyberspace, p. 3 (Routledge, New York, 2003)

12. J.M. Norman, From Gutenberg to the Internet: A Sourcebook on the History of Information Technology, p. 6 (Historyofscience, California, 2005)

13. P.R. Astuti, Meredam Bullying: 3 Cara Efektif Mengatasi Kekerasan Pada Anak, p. 3 (Grasindo, Jakarta, 2008)

14. O. Saracho, Contemporary Perspectives on Research on Bullying and Victimization in Early Childhood Education, p. 188 (Information Age Publishing, Charlotte, 2016)

15. B. Arrigo, Encyclopedia of Criminal Justice Ethics, p. 220-221 (SAGE Publication, California, 2014)

16. S. Chadwick, Impacts of Cyberbullying, Building Social and Emotional Resilience, p. 4-5 (Springer, North Ryde Australia, 2014)

17. P. De Cruz, Perbandingan Sistem Hukum: Common Law, Civil Law, and Socialist Law, Trans.N. Yusron, p. 4 (Nusa Media, Jakarta, 2016)

18. A. Watson, Legal Transplants: An Approach to Comparative Law, p. 16 (University of Georgia Press, Georgia, 1993)

19. W. Menski, Perbandingan Hukum Dalam Konteks Global Sistem Eropa, Asia, dan Afrika, p. 10 (Nusa Media, Bandung, 2016)

20. M. Borba, Membangun Kecerdasan Moral (Tujuh Kebajikan Utama Agar Anak Bermoral Tinggi), p. 7-8 (Gramedia Pustaka Utama, Jakarta, 2008)

21. N. A. Hassan, Digital Privacy and Security Using Windows: A Practical Guide, p. 84 (Apress, New York, 2017) 
22. D.W. Ningrum, Alat Bantu Untuk Pantau Anak Internetan, https//inet.detik.com/konsultasi-cyberlife/d-3202659/alat-bantu-untuk-pantau-anakinternetan appdev.2018.04.008

23. M. Chatib, Orangtuanya Manusia: Melejitkan Potensi dan Kecerdasan Dengan Menghargai Fitrah Setiap Anak, p. 190 (PT Mizan Pustaka, Bandung, 2012)

24. I. Kartila, Anak-anak Cenderung Meniru Adegan Di Televisi, https://tekno.kompas.com/2012/05/28/22490165 appdev.2018.04.009

25. E. Kristian, KPI dan Kemen Kominfo Diminta Tegas agar Stasiun TV Jera, https://nasional.kompas.com/read/2016/01/28/00034711/KPI.dan.Kemen.Kominfo.Di minta.Tegas.agar.Stasiun.TV.jera appdev.2018.04.009

26. L. Victor and F. Ana, Towards Suicide Prevention : Early Detections of Depression on Social Media in Social Media, p.428-436 (2017)

27. M. Horowitz and D. M. Bollinger, Cyberbullying in Social Media Within Educational Institutions: Featuring Student, Employee, and Information, p. 1 (Rowman \& Littlefield, London, 2014)

28. K. E. Dill-Shackleford, How Fantasy Becomes Reality: Information and Entertainment Media in Everday Life, p. 82 (Oxford University Press, United States, 2016)

29. M. Khosrowpour, Cyber Behavior: Concepts, Methodologies, Tools, and Applications, p. 934 (Information Science Reference, United States, 2014)

30. J. A. Decesare, Streaming Video Resources for Teaching, Learning, and Research, p. 12 (Library Technology Reports, Chicago, 2014)

31. S. Feinstein, From the Brain to the Classroom: the Encyclopedia of Learning, p. 515 (Greenwood, California, 2014)

32. E. Reed, Cyberbullying on Smallwords, appdev.2018.04.012 